\title{
Zoonotic Bacterial Infection
}

National Cancer Institute

\section{Source}

National Cancer Institute. Zoonotic Bacterial Infection. NCI Thesaurus. Code C35373.

A bacterial infection that is transmitted from animals to people. 